\title{
THE USE OF MEDIA FOR SCIENCE TEACHING IN ISLAMIC SCHOOLS
}

\author{
Abd. Ghofur \\ STKIP PGRI Lamongan \\ email: ghofurkita@yahoo.com
}

\begin{abstract}
This paper aims to describe the use of media in science learning in terms of three indicators, namely: a) diffusion of innovation, $b$ ) implementation and institutionalization, and c) policies and regulations. This research was conducted for four months using qualitative descriptive design with data collection technique through questionnaire, interview, and observation. The subjects of the study were class VII on MTs Putra Putri Lamongan and MTs Maslakul Huda Paciran selected by purposive sampling. The results showed that science teachers in Islamic schools utilize various media of learning in the form of visual and audio visual media designed as a medium of teaching science, for example LCD projector, props, etc. In addition, teachers also develop their own simple media designed to be utilized in science teaching, such as cloth, water, soil, and so forth. Technically, teachers are documenting the use of instructional media in the Lesson Plans (RPP) which refer to the 2013-curriculum format, but the RPP is not always brought during the learning process. In addition, school policy does not provide written regulations for teachers to use the media in the learning process.
\end{abstract}

Keywords: the use of media, science teaching

\begin{abstract}
Abstrak: Tulisan ini bertujuan untuk mendeskripsikan pemanfaatan media dalam pembelajaran sains yang ditinjau dari tiga indikator, yakni a) difusi inovasi, b) implementasi dan pelembagaan, serta c) kebijakan dan regulasi. Penelitian ini dilakukan selama empat bulan menggunakan rancangan deskriptif kualitatif dengan teknik pengumpulan data melalui angket, wawancara, dan observasi. Subyek penelitian adalah kelas VII pada MTs Putra Putri Lamongan dan MTs Maslakul Huda Paciran yang dipilih secara purposive sampling. Hasil penelitian menunjukkan bahwa guru sains di sekolah Islam memanfaatkan ragam media pembelajaran dalam bentuk media visual dan audio visual yang didesain sebagai media pembelajaran sains, misal LCD proyektor, alat peraga, dll. Selain itu, guru juga mengembangkan media sederhana sendiri yang didesain untuk dimanfaatkan dalam pembelajaran sains, misalnya kain, air, tanah, dan lain sebagainya. Secara teknis, guru mendokumentasikan pemanfaatan media pembelajaran tersebut dalam Rencana Pelaksanaan Pembelajaran (RPP) yang mengacu format Kurikulum 2013, namun RPP tersebut tidak selalu dibawa saat proses pembelajaran. Selain itu, kebijakan sekolah tidak memberikan regulasi secara tertulis untuk guru melakukan pemanfaatan media dalam proses pembelajaran.
\end{abstract}

Kata Kunci: pemanfaatan media, pembelajaran sains

\section{INTRODUCTION}

Science is one of the lessons deemed important by the world community, the proof of students' science ability to be a benchmark for the evaluation of education both nationally and internationally. National evaluation is conducted through the National Examination (UN) every year, while the international evaluation is conducted by the Program for International Students Assessment (PISA) and Trends International Mathematics and Science Study (TIMSS) conducted every three years. The surprising data is that both national and international evaluations almost always place the value of science skills of Indonesian students lower if compared with other lessons tested. This is reinforced by the findings of Gok \& Silay (2008) that science learning outcomes are lower than other fields, this is because science is considered as a subject that is difficult to understand by most students so that students are less interested in learning science. This is also explained by Liliasari (2009) that many students are less fond of 
learning science because it is difficult and unattractive.

Students' dislike toward science lessons becomes an important note for teachers to reflect on the learning process that has been done. It could be a learning activity conducted by monotonous teachers and is transfer of knowledge only. It is also expressed by Mahyudin (2007) that students only study science as a product, memorize theoretical and legal concepts so as to study science only at the low level of cognitive domain. When the process of learning science is just a process of moving material from book to student of course the activity feels boring. According to Arsyad (2004), the interactions that occur during the learning process are influenced by the environment, which consists of students, teachers, librarians, principals, materials or materials (books, modules, magazines, video or audio recordings and the like) and various learning resources and facilities. A teacher or educator is one element of the decisive factor in the success of the learning process. However, it must be supported by other elements. Therefore, in addition to the use of appropriate learning methods, teachers also need to utilize learning media and other learning resources that can make learning science become more meaningful.

According Suryobroto (2001), the use of media is the use of systematic learning resources. The decision to try or use learning resources should take into account student characteristics and learning objectives. this utilization in charge of how in theory and practice a process and learning resources are utilized for the benefit of learning. This utilization area consists of media usage, media distribution, implementation and institutionalization and policies and regulations. Meanwhile, according to Hamalik (2001) the learning media have no small benefits in teaching and learning activities, such as reducing verbalism, enlarging students' attention, a more stable learning process, providing real experience, providing knowledge that is not obtained by other means and help the development of efficiency a deeper and more diversity in learning. In addition, according to Rohani (2004), learning media can also provide practical value, among them can overcome differences in children who lack experience in children with more experience, can also replace objects that are too big or too small and can be brought to the classroom. Learning media also allows for direct interaction between students and their environment and provides a thorough and concrete experience.

The quality of science learning is strongly influenced by the quality of teachers, especially the competence in the utilization of instructional media. According to Mulyasa (2009), one of the skills related to instructional media is the skills to hold variations that must be mastered by educators with the aim to overcome the boredom of learners, to always be enthusiastic, diligent, and full of participation. Variation in learning is a change in the process of activities that aim to improve motivation to learn and reduce saturation and boredom. Variations in learning can be done include: in the use of learning methods, the use of media and learning resources, giving examples and illustrations, and in the interaction and activities of learners. The same thing is also described by Sudjana (2001) that the accuracy of the use of learning media cannot be separated from the educator's understanding of the variety and characteristics of the media. Each type of learning media has its own peculiarities. This needs to be part of the skills and skills of teachers in accordance with the 
competencies that must be owned to a professional teacher.

In connection with these various descriptions, this paper attempts to examine the use of media in science teaching in

\section{RESEARCH METHODS}

This research is a qualitative descriptive research that aims to know the use of media in science learning in Islamic Schools in Lamongan. The subjects of the study were class VII in MTs Putra-Putri Lamongan and MTs Maslakul Huda Paciran Lamongan selected by purposive sampling. The reasons for choosing both schools are a) the representation of pesantren-based schools and non-pesantren Islamic schools, b) the two schools have
Islamic schools in Lamongan which is one of the research activities entitled "Strengthening Education of Science in Islamic Schools in Indonesia.

more than two study groups in each class for experimental purposes in subsequent research. Technique of collecting research data using questionnaires, interviews and observations for four months, starting from January to April 2017. In this study, conducted an analysis of the results of data collection on the use of media in science learning in three aspects, namely a) the diffusion of innovation, b) implementation and institutionalization, and c) Policies and regulations.

Table 1. Description of area of use in instructional technology

\begin{tabular}{l|l}
\hline \multicolumn{1}{c|}{ Use Area } & \multicolumn{1}{c}{ Explanation } \\
\hline Innovation Diffusion & $\begin{array}{l}\text { The process of updating the various components required in } \\
\text { the delivery of materials, adopted and utilized by the school's } \\
\text { citizens so that the medium can be accepted and used in } \\
\text { everyday learning to improve the quality, effectiveness and } \\
\text { efficiency of teaching }\end{array}$ \\
\hline Implementation and & $\begin{array}{l}\text { The use of materials and learning strategies in a real-time } \\
\text { routine in the structure of the teaching process so that teaching } \\
\text { innovation can be integrated in the structure and organization } \\
\text { of teaching. }\end{array}$ \\
\hline Policies and Regulations & $\begin{array}{l}\text { The rules and concrete actions of users or decision makers in } \\
\text { educational unit levels to accept such innovations and enforce } \\
\text { them in the teaching policy }\end{array}$ \\
\hline
\end{tabular}

\section{RESULTS AND DISCUSSION Innovation Diffusion}

Not much different from the students in other schools, science lessons are also considered difficult and boring for most students MTs Putra Putri Lamongan and MTs Maslakul Huda Paciran, especially if the material count. Because, if the science lessons on the subject matter count, students tend to memorize formulas and the like, it is considered difficult and boring. In addition, in these two schools despite having a science laboratory, but the existing practicum media is still not used maximally, so the process of science teaching is more done in the classroom. Nevertheless, during the four months of observing science teaching, teachers in the two schools occasionally make teaching innovations by utilizing the media.

In MTs Putra Putri Lamongan, due to the limitations of the practicum tool, teachers make innovations by creating simple media. One of them, the teacher made a simple media about chemicals on the fabric. Does this fabric contain chemicals or not?. Practically, students bring themselves a patchwork, then 
teachers and students identify together in class, which ones are natural fibers, and which are artificial fibers. Identification is done through the burning of the cloth with the supervision of the teacher, the way of identification by kissing the cloth, whether it contains natural fibers or not. Another example is to test foods containing carbohydrates that are dropped with iodine.

The activities of finding, finding, and developing quality learning media depend on the creativity of teachers and students. For example in cell material, in the handbook there is no way to make it, if using the image media it is common, innovation of teachers by dividing the class into several groups then create a cell media with three dimensional images. The threedimensional image media comes from cork, palm, ribbon, or pipe that is no longer in use. There are many ways that teachers can do to cultivate ideas, reasoning and innovation in science learning. Stages, teachers explain first the material, for example why there is a mask ?, it is impossible to hold the mouth and nose with the hand in a state of driving if there is dust. Based on these conditions then comes cloth cover to protect the body so as not to be disturbed by dust.

In addition to reference books owned by students, teachers and students also use the Internet as an alternative source of teaching. They access the internet by using HP, because in MTs Putra Putri facilitated Wireless Fidelity (Wifi). The use of internet in learning activities tends to be group. Usually teachers use the internet to download video or animated images related to the material to be submitted. Teachers use the video as an apperception to stimulate students to understand the core material to be learned. With this strategy, students know early on in terms of the material they will learn and the teacher is phenomena of everyday in apperception at the beginning of learning. This is done almost every time science teaching.

In addition, in MTs Maslakul Huda Paciran also provided a multimedia room easier to enter into the material to be delivered.

While in MTs Maslakul Huda Paciran, teaching innovation is done through the use of simple media created by science teachers. For example an explanation of environmental sustainability materials, teachers use soil media, sand, water in mineral bottles and grass placed on trays. The media is used to demonstrate the difference between the forest land that is still there with a tree that is analogous to the grass and forest land bare.

The making of simple instructional media is done solely by teachers on their initiative in accordance with the science material presented. While the practicum items that exist in the Science Laboratory is fully the authority of the school. The utilization of learning resources by students, especially through the internet is quite good. Because schools facilitate internet access via wifi network. While this is the main source of child learning from textbooks and reference books in the library. The use of the Internet is also sometimes done by students when given the task by the teacher to seek reference material on the internet. This is often done, because the average student has HP to use to access task material via the internet. For students who do not have HP computer lab is provided or sometimes there is also to the internet cafe.

Teachers seek to find, and develop quality teaching media by asking a lot, sharing fellow science teachers and browsing on the internet. In classroom teaching, the teacher explains the concepts of science and its relation to the experiences and natural phenomena of everyday life. It becomes a teacher strategy in motivating children in science teaching. The teacher conveys the concepts of science and its relation to the experiences and natural used by all teachers in scheduled delivery of material. The space is used for audio visual based teaching that visualizes the material so that it is easily understood by the students. To overcome the limitations of practicum media in science laboratories, 
what teachers often do is apply classroom demonstration methods. Even if you want to do practice in the laboratory, should be in small groups, if large groups are still not possible. Because the room is spacious and can accommodate many students, but the equipment labs are limited.
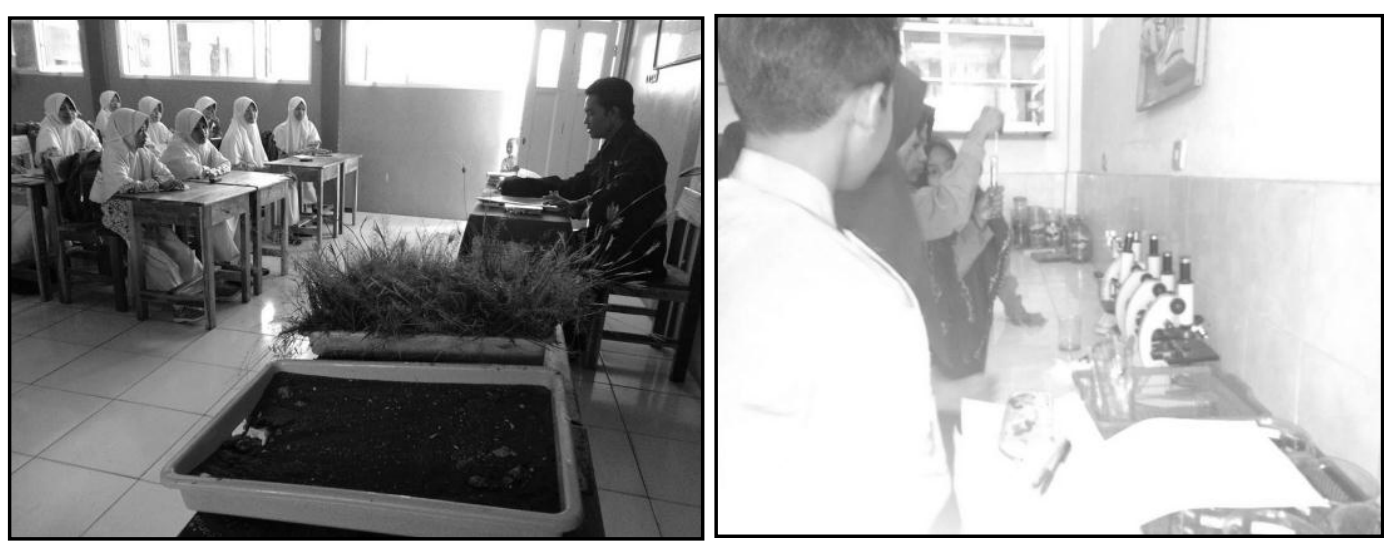

Figure 1. Innovation of teachers in the use of media for science teaching, a) teachers use simple media in MTs Maslakul Huda class, b) simple practicum students in Laboratory of MTs Putra Putri Lamongan

\section{Implementation and Institutionalization}

Based on the observation, in MTs Putra Putri Lamongan, there are quite a lot of science teaching media in the laboratory, both for biology and physics teaching media, but not well utilized due to limited laboratory space. In addition, in each class is also equipped LCD Projector. Then, on each wall of the class are also affixed to the works of students. In addition, teachers also make local modifications in the use of teaching methods. For example, in teaching science teachers apply shopping methods that are collaborated with the use of used goods as a medium of teaching. In addition, teachers have also brought plants as media observed in the classroom.

Teachers in classroom teaching provide an explanation of the concepts of science and its relation to the experiences and natural phenomena of everyday life. For an explanation of the concepts of science associated with the experience and natural phenomena of everyday life can be more intriguing students in learning the material. For example, practicums using a microscope in the school laboratory belonging to the old tool, students are less satisfied with the results of the lab. Then the teacher recounts his experience using a variety of microscopes. The experience makes students enthusiastic to listen and cultivate high student curiosity. In addition, teachers also associate science with everyday technology. For example the use of a fan in the class which is a change of electrical energy into motion. For example, again the material about the solar system, how to observe the star, that is by using binoculars. Because in the school there is no binocular, it can be seen with software that can know the stars without having to use binoculars.

Teachers use the internet in schools to develop materials and methods in science teaching. For example on materials that require factual review, teachers usually seek additional references by using the internet. The material gained from the internet is practiced in learning using discussion and other methods. Teachers who are looking for material on the internet 
as a material and source of problems, then students think how to solve the problem. Master once used a multimedia show containing Islamic teachings to explain the process of science, but only limited to the animated video as an apperception then the teacher associate the video with the material being studied.

While in MTs Maslakul Huda, students find difficulties in science teaching, especially on the material physics, especially on memorizing the formulas and calculating metrics. But when entering on biology materials, students are very enthusiastic to follow. Because, students feel more able to imagine in real terms biological material, while the material physics tend to be a lot of material count so students look lazy.

Because of the limited facilities and infrastructure of learning science in schools, teachers make their own media, but the making of teaching media is not done every meeting, but tailored to certain materials that do require the existence of teaching media. Sometimes teachers give assignments to students to create teaching media for shared learning activities.

In addition, teachers have also practiced using a simple thermometer tool through teaching videos. However, in the implementation of the results that are exemplified in the teaching video with the students practiced differently result. This is possible because the equipment used is also different thermometers. Because the tool that is used for practice is a simple thermometer of homemade results. Nevertheless the teacher provides a scientific explanation why there is a difference between the display of teaching videos with the results of student practice.

In the two schools that are the subject of this research, media utilization planning in science teaching activities conducted by teachers is also documented in the Lesson Plans (RPP) that refer to the Curriculum format 2013. However, in practice, teachers rarely bring the RPP while in the teaching process. RPP is made as a reference that has been studied previously and made as a document only. The reason, sometimes RPP made by the teacher is not in accordance with the situation and conditions, such as time that does not fit, the condition of students, and others. In addition, sometimes unscheduled school activities are sudden, such as announcements and other time-consuming assignments that cause teachers to rarely bring RPP in the classroom to teach. The teacher believes that the essence of teaching is the most important is the delivery of material in accordance with the Basic Competence (KD) that has been formulated previously. Thus, although without bringing the lesson plan, the teacher has understood the substance of the material and the use of the media that needs to be delivered in the science teaching process.

\section{Policies and Regulations}

In the two Islamic schools that were the subject of the study, the teaching innovation in media utilization was left entirely to the science teacher. Schools only provide laboratories and instruments, LCD Projectors, internet and more. But how innovation in increasing the teaching activities become the responsibility and obligation of teachers. Both in MTs Putra Putri Lamongan and MTs Maslakul Huda there is no written policy that binds teachers to use or create media on every lesson. The policy is given by the principal through an appeal in each teaching evaluation meeting so that the teacher can improve the innovation in the teaching activities.

In MTs Putra Putri Lamongan, laboratory equipment is quite a lot, but constrained on the space that is less 
representative. As a result, science teaching activities are mostly done in more tutorial classrooms. As long as it does not apply the standardization of science teaching strategy, science teaching is adapted to the application of learning as it is in the curriculum 2013 which is technically submitted to their respective science teachers. But the future policy according to the principal, science teachers are invited to continue to learn, at least national standards. In addition, the headmaster program in the last year in the management of science laboratory programmed oneweek student dues Rp, 1000, -. This fee each class is collected in the treasury of each class to purchase the needs of some practical activities. Useful if there are activities of science practice, or the manufacture of media and management of books in the class is taken from the money class. Another principal's policy is required by 5 general subjects, one of which science lessons must have the completeness of textbooks, media and teaching tools. The policy is also supported by the student guardian. Another new policy is planned from next year, at least in a semester there is science teaching done outside the classroom.

In MTs Maslakul Huda Paciran there is also no policy that specifically binds teachers in the use of media in science teaching. Schools provide science labs and multimedia spaces that can be used to maximize teaching activities. But the use of space can not be done routinely because it must be alternated with students MA Maslakul Huda who is in a complex. In addition, there is no standardized teaching strategy in this school. All related teaching activities are left entirely to their respective teachers. However, the principal still exercises control, especially in relation to changes in teaching patterns from the past to the present. Technically, the management of science education becomes the authority of each section. If it is related to the management of the laboratory, it is entirely submitted to the infrastructure section. If the science learning equipment is lacking, the teacher directly coordinates with the school infrastructure. All attempted to be facilitated by the school. MTs Maslakul Huda has a science laboratory, but has not fully met the ideal standards set by the Government. The space is spacious enough, the equipment is incomplete, but there are in accordance with the applicable minimum standards.

\section{CONCLUSION}

Science teaching by using the media can improve the enthusiasm of students in learning activities both in class and outside the classroom. Technically, teachers are documenting the use of instructional media in the Lesson Plans (RPP) that refer to the 2013-curriculum format, but the RPP is not always brought during the learning process. In addition, schools do not provide written policies for teachers to use the media in the learning process. The principal's policies are in the form of instructions and suggestions to every teacher in every academic evaluation meeting.

\section{ACKNOWLEDGMENTS}

Acknowledgments are given to the Indonesian Consortium for Religious Studies for research program entitled "the strengthening of science education in Islamic schools in Indonesia". Further thanks to the United States Agency for International Development (USAID) and National Academy of Sciences (NAS) who has supported the research program. 


\section{REFERENCE}

Arsyad, A. (2004). Media Pembelajaran. Jakarta: PT. Raja Grafindo Persada.

GOK, T. \& Silay, I. (2008). Effcts of Problem Solving Strategies Teaching on The Problem Solving Attitudes of Cooperative Learning Group in Physics Education. Journal of Theory and Practice in education. 4 (2):253-266.

Hamalik, O. (2001). Kurikulum dan Pembelajaran. Jakarta: Bumi Aksara.

Liliasari. (2009). Tantangan Pembelajaran Sains di Abad ke-21 dan Kiat-Kiat Penanggulangannya. Seminar Nasional Pendidikan IPA Asosiasi Guru Sains Indonesia (AGSI) ke-V. Bandung.
Mulyasa, E. (2009). Menjadi Guru Profesional (Menciptakan Pembelajaran Kreatif dan Menyenangkan). PT Remaja Rosdakarya: Bandung, Indonesia.

Rohani, A. (2004). Pengelolaan Pengajaran. Jakarta: PT Rineka Cipta.

Sudjana, N. (2001). Media Pembelajaran (Pembuatannya dan Penggunaannya). Bandung: PT Remaja Rosdakarya.

Suryobroto, A. S.(2001). Diktat Mata Kuliah Teknologi Pembelajaran Pendidikan jasmani. Yogyakarta: FIK 